Jurnal Laut Khatulistiwa, Vol. 4. No. 1(Febuari, 2021), Hal. 56-63.

ISSN : 2614-6142 (Printed), 2614-8005 (Online)

http://jurnal.untan.ac.id/index.php/lk

JURNAL LAUT

KHATULISTIWA

\title{
Struktur Pola Vegetasi Mangrove di Desa Sungai Kupah Kecamatan Sungai Kakap Kabupaten Kubu Raya
}

\section{Structure Patterns of Mangrove Vegetation di Desa Sungai Kupah Kecamatan Sungai Kakap Kabupaten Kubu Raya}

\author{
Muhardianshah $^{1 *}$, Arie.A Kushadiwijayanto ${ }^{2}$, Yusuf.A Nurrahman' ${ }^{2}$ \\ 1 Program Studi Ilmu Kelautan, FMIPA Universitas Tanjungpura, Pontianak, Indonesia \\ ${ }_{1}^{1}$ Laboratorium Ilmu Kelautan, FMIPA Universitas Tanjungpura, Pontianak, Indonesia \\ *E-mail : muhardian.anaklaut@gmail.com
}

Received : 10 Febuari 2021; Accepted: 23 Febuari 2021

Published: 28 February (C) Author(s) 2020. This article is open access

\begin{abstract}
The Defined Mangrove vegetation as the type of the forest ecosystem that grows in the area of tidal water, such as on the beach and around the estuary of the river. The purpose of this research to find the structure patterns of vegetation mangrove in the Village of Sungai Kupah. The research in 3 stations is a by using method purposive sampling. The defined in each station into 3 plot observations measured perpendicular from direct the beach towards land using the combination of quadran in transect by the criteria of use tree, sapling and seedling. With the distance between the plots of each other her adjusting conditions the mangrove in the field. The result of getting 5 kinds of mangrove namely Avicennia marina, A. lanata, Rhizophora apiculata, Sonneratia alba, and Nypa fruticans. The mangrove type dominated, for trees criteria is A. marina, sapling criteria are N.fruticans and are A. marina. Significant Value Index for trees type ranges $62.67-300 \%$, for sapling type range 19,55 - 68,57. The diversity is relatively moderate, except on Station 2 and 3 with diversity level of the seedling relatively low. The results of the measurement parameters still are very supportive for the growth of mangrove in the Village Sungai Kupah
\end{abstract}

Keywords : Village Kupah River, Composition Structure, Vegetation, Mangrove

\begin{abstract}
Abstrak
Hutan mangrove dapat didefinisikan sebagai tipe ekosistem hutan yang tumbuh di daerah batas pasangsurut air seperti di pantai dan sekitar muara sungai. Tujuan penelitian ini untuk mengetahui struktur komposisi vegetasi mangrove dan pola zonasi mangrove di Desa Sungai Kupah Kecamatan Sungai Kakap. Penelitian ini 3 stasiun yang ditentukan dengan menggunakan metode purposive sampling. Setiap stasiun dibagi menjadi 3 plot pengamatan yang diukur tegak lurus dari garis pantai kearah darat menggunakan kombinasi metode transek dan metode kuadran dengan kriteria pohon, pancang, semai dengan jarak setiap antar plot lainnya menyesuaikan kondisi mangrove di lapangan. Hasil penelitian mendapatkan 5 jenis mangrove yaitu Avicenia marina, Avicenia lanata, Rhizopora apiculata, Soneratia alba, Nypa frutican. Jenis mangrove yang mendominasi tingkat pohon mangrove jenis $A$. marina, tingkat pancang $N$. fruticans dan tingkat semai adalah mangrove jenis A. marina. Kisaran Indeks Nilai Penting tingkat pohon pada lokasi penelitian $62.67 \%$ - $300 \%$, INP tingkat pancang berkisar antara $19.55 \%-68.57 \%$. Indeks keanekaragaman tergolong sedang, kecuali pada Stasiun 3 tingkat semai tergolong rendah. Hasil pengukuran parameter lingkungan masih sangat mendukung untuk pertumbuhan mangrove di Desa Sungai Kupah Kecamatan Sungai Kakap.
\end{abstract}

Kata kunci : Desa Sungai Kupah, Struktur Komposisi, Vegetasi, Mangrove

\section{Pendahuluan}

Hutan mangrove umumnya ditemukan hampir di seluruh wilayah pesisir dan laut
Indonesia yang memiliki hubungan langsung terhadap pasang surut air laut di sepanjang pesisir. Hutan mangrove berperan sebagai salah satu penunjang perekonomian 
masyarakat pesisir. Secara ekologis, hutan mangrove juga memiliki banyak fungsi yaitu sebagai habitat biota laut, perlindungan wilayah pesisir dan pantai, penyerapan karbon, pencegah terjadinya abrasi dari berbagai ancaman sedimentasi, pemecah gelombang,dan tempat pemijahan bagi ikan yang hidup di laut bebas (Tarigan, 2008). Berdasarkan Kementerian Kehutanan Republik Indonesia (2013), secara umum jenis tanaman mangrove di Indonesia terdiri atas 202 jenis dan 150 jenis diantara nya terdapat di wilayah Provinsi Kalimantan Barat. Diketahui bahwa hutan mangrove di Kalimantan Barat secara umum sudah berupa hutan mangrove sekunr atau bekas tebangan. Hutan Mangrove primer yang masih tersisa di Provinsi Kalimantan Barat diketahui terdapat di Kabupaten Kubu Raya. Hutan Mangrove di Kabupaten Kubu Raya seluas 55.439 hektar (31\% dari seluruh luas daerah).

Desa Sungai Kupah, Kecamatan Sungai Kakap merupakan bagian dari Kabupaten Kubu Raya, Provinsi Kalimantan Barat yang terletak di daerah pesisir yang dekat dengan muara Sungai Kapuas. Hutan mangrove yang terdapat di pesisir Desa Sungai Kupah berpotensi mengalami degradasi akibat penebangan mangrove untuk berbagai aktivitas manusia seperti dijadikan untuk sebagai alih fungsi lahan seperti jalur transportasi, dan tempat wisata.

Oleh karena itu perlu dilakukan antisipasi dalam kerusakan hutan mangrove yang lebih buruk dikawasan ini, maka perlu usaha-usaha yang serius dalam pengelolaannya. Salah usaha yang dapat dilakukan satunya adalah dengan menyediakan data tentang struktur dan komposisi vegetasi mangrove (meliputi kerapatan, kerapatan relatif, frekuensi, dominansi, indeks nilai penting dan indeks keanekaragaman) yang ada di Desa Sungai Kupah saat ini.

\section{Metodologi Penelitian}

\subsection{Waktu dan Tempat}

Penelitian telah dilakukan pada Bulan Januari s/d Mei 2019 di Desa Sungai Kupah Kecamatan Sungai Kakap, Kabupaten Kubu Raya, Kalimantan Barat (Gambar 1)

\subsection{Metode Penelitian}

Penentuan lokasi penelitian menggunakan metode purposive sampling dengan 3 stasiun pengamatan berdasarkan rona lingkungan yang berbeda. Stasiun 1 terletak pada lokasi yang dekat dengan muara sungai, Stasiun 2 lokasi yang terletak dekat pemukiman penduduk. Stasiun 3 terletak di daerah yang jauh dari pemukiman penduduk atau hutan alami. Pengambilan data analisis kondisi hutan mangrove dilakukan menggunakan metode petak berganda yaitu kombinasi metode transek (transect methods) dan metode kuadrat (quadrat methods) (Fachrul, 2008) yang diukur tegak lurus dari garis pantai ke arah darat. Jarak antara plot satu dengan plot lainnya sesuai dengan kondisi mangrove.

Setiap jalur transek dibagi menjadi tiga kuadran berukuran dengan pembagian 3 plot. Plot pertama berukuran 1 x 1 meter untuk kategori semai (tinggi sampai 1,5 m), plot $5 \times 5$ meter untuk kategori pancang (tinggi lebih dari 1,5 m dengan diameter kurang dari $10 \mathrm{~cm}$ ), dan plot 10 x 10 meter untuk kategori pohon (diameter 10 - $19 \mathrm{~cm}$ ). Pengukuran parameter fisika-kimia pada struktur komunitas mangrove terdiri dari salinitas, $\mathrm{pH}$, suhu, dan substrat, yang dilakukan 3 kali ulangan di setiap stasiun pengamatan (Gambar 2)

\subsection{Pengolahan Data}

Menurut Indriyanto (2006) Analisis deskriptif kuantitatif merupakan data yang diperoleh dilapangan ditabulasi dan dianalisis untuk menentukan besaran Kerapatan, Kerapatan Relatif, Frekuensi, Frekuensi Relatif, Dominansi, Dominansi Relatif dan Indeks Nilai Penting serta Variabel Tingkat Keanekaragaman Jenis. Analisis Kerapatan Jenis, Kerapatan Relatif, Frekuensi Jenis, Frekuensi Relatif, Dominansi, Dominansi Relatif dan Indeks Nilai Penting (INP).

Kerapatan adalah jumlah individu per unit luas atau per unit volume. Dengan kata lain, densitas merupakan jumlah individu organisme per satuan ruang. Untuk kepentingan analisis komunitas tumbuhan, istilah yang mempunyai arti sama dengan densitas dan sering digunakan adalah kerapatan diberi notasi $\mathrm{K}$.

$$
\mathrm{K}=\frac{\text { Jumlah Individu Suatu Jenis }}{\text { luas seluruh petak(plot) }}
$$


Jurnal Laut Khatulistiwa, Vol. 4. No. 1 (Febuari, 2021), Hal. 56-63.

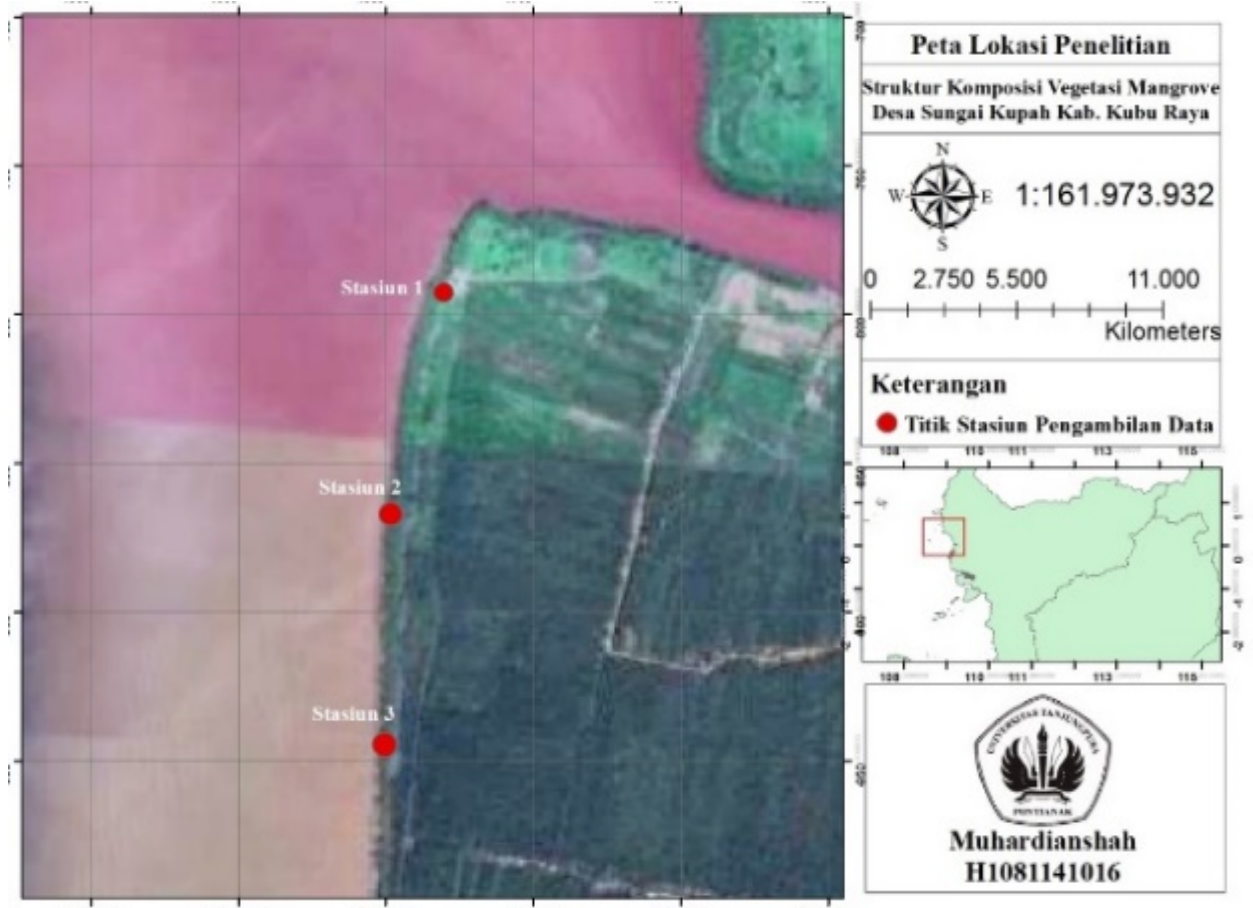

Gambar 1. Lokasi penelitian

$$
\mathrm{KR}=\frac{\text { kerapatan suatu jenis }}{\text { kerapatan seluruh jenis }} \times 100 \%
$$

Dengan K dan KR masing-masing adalah kerapatan dan kerapatan relatif.

Frekuensi merupakan suatu besarnya intensitas diketemukannya suatu spesies organisme dalam pengamatan keberadaan organisme pada komunitas tumbuhan. Frekuensi spesies (F) dan Frekuensi relatif dapat dihitung dengan rumus sebagai berikut

$\mathrm{F}=\frac{\sum \text { petak contoh ditemukan suatu jenis }}{\sum \text { seluruh petak contoh }}$

$\mathrm{F}=\frac{\text { Frekuensi suatu jenis }}{\text { frekuensi suatu jenis }} \times 100 \%$

Dominansi adalah parameter yang menyatakan tingkat terpusatnya dominasi (penguasaan) spesies dalam suatu komunitas. Penguasaan atau dominansi spesies dalam komunitas bisa terpusat pada satu spesies, atau pada banyak spesies yang dapat diperkirakan dari tinggi rendahnya indeks dominansi (ID).

$\mathrm{D}=\frac{\text { luas bidang dasar suatu jenis(LBDS) }}{\text { luas petak contoh }}$
$\mathrm{DR}=\frac{\text { Dominansi suatu jenis }}{\text { dominansi seluruh jenis }} \times 100 \%$

Indeks Nilai Penting (INP) adalah parameter kuantitatif yang dapat dipakai untuk menyatakan tingkat dominansi spesiesspesies dalam suatu komunitas tumbuhan. Untuk mengetahui jenis dominan disetiap tingkat pertumbuhan digunakan metode indeks nilai penting (INP), dimana INP terdiri atas kerapatan relatif, frekuensi relatif, dan dominansi relatif dengan nilai maksimum 300 $\%$ pada tingkat pohon dan tingkat tiang sedangkan untuk tingkat semai dan tingkat pancang nilai maksimum INP ialah 200\% terdiri dari jumlah kerapatan relatif (KR) dan frekuensi relatif (FR) Fachrul (2008). Dengan demikian INP dapat dituliskan dengan rumus sebagai berikut. Rumus tingkat pancang dan semai dengan :

Indeks Nilai Penting (INP) $=\mathrm{KR}+\mathrm{FR}$

Rumus tingkat pohon dan tiang dengan :

Indeks Nilai Penting (INP) $=\mathrm{KR}+\mathrm{FR}+\mathrm{DR}$

Dimana:

INP = Indeks Nilai Penting (\%)

$\mathrm{KR}=$ Kerapatan Relatif (\%) 
Jurnal Laut Khatulistiwa, Vol. 4. No. 1 (Febuari, 2021), Hal. 56-63.

FR = Frekuensi Relatif (\%)

DR = Dominansi Relatif

Keanekaragaman spesies merupakan ciri tingkatan komunitas berdasarkan organisasi biologinya. dengan rumus sebagai berikut:

$\mathrm{H}^{\prime}=-\Sigma\{\mathrm{ni} / \mathrm{N}\} \operatorname{Ln}\{\mathrm{ni} / \mathrm{N}\}$

Dimana:

$\mathrm{H}^{\prime}$ = Indeks keanekaragaman Shanno-Wiener

$\mathrm{Ni}=$ Jumlah individu jenis ke- $i$

$\mathrm{N}=$ Jumlah total individu

$\mathrm{Ln}=$ Logaritma natural

\section{Hasil dan Pembahasan}

\subsection{Komposisi Vegetasi Mangrove}

Pada penelitian yang telah dilakukan untuk komposisi vegetasi mangrove diperoleh jenis vegetasi mangrove sebanyak 5 (lima) jenis vegetasi mangrove yang termasuk kedalam 4 famili. Jenis-jenis mangrove yang diidentifikasi secara keseluruhan dapat diketahui pada. Komposisi jenis mangrove tingkat pohon yang tertinggi pada lokasi pengamatan adalah $A$. marina dan yang terendah adalah $N$. frtican. Jenis $A$. marina memiliki komposisi yang tertinggi karena jenis ini mampu beradaptasi dengan baik terhadap kondisi lingkungan dilokasi penelitian (Tabel 1).

\subsection{Kerapatan Mangrove}

Kerapatan adalah jumlah individu per unit luas atau per unit volume. Dengan kata lain, densitas merupakan jumlah individu organisme per satuan ruang. Untuk kepentingan analisis komunitas tumbuhan, istilah yang mempunyai arti sama dengan densitas dan sering digunakan adalah kerapatan diberi notasi $\mathrm{K}$.

Hasil kerapatan jenis pada Stasiun 1 tingkat pohon yang tertinggi adalah $A$. marina dengan nilai kerapatan sebesar 67 pohon/ha. Jenis mangrove yang memiliki kerapatan tertinggi pada tingkat pohon di Stasiun 2 adalah $A$. lanata yang memiliki nilai 100 pohon / ha. Sedangkan Jenis mangrove yang memiliki kerapatan tinggi ditemukan pada Stasiun 3 tingkat pohon adalah A. marina, A. lanata dan $N$. fruticans dengan nilai 100 pohon / ha. Kerapatan mangrove tingkat pancang tersusun atas 5 jenis mangrove yang ditemukan pada setiap stasiun dimana Stasiun 1 terdapat atas 3 jenis mangrove, Stasiun 2 terdapat 5 jenis mangrove dan Stasiun 3 terdapat 3 jenis mangrove. Kerapatan mangrove paling tinggi pada tingkat semai diperoleh jenis mangrove A. marina dan A. lanata memiliki nilai sebesar 6.666 pohon/ha sedangkan nilai kerapatan jenis mangrove terendah adalah $R$. apiculata dengan memiliki nilai 833 pohon/ha (Tabel 2)

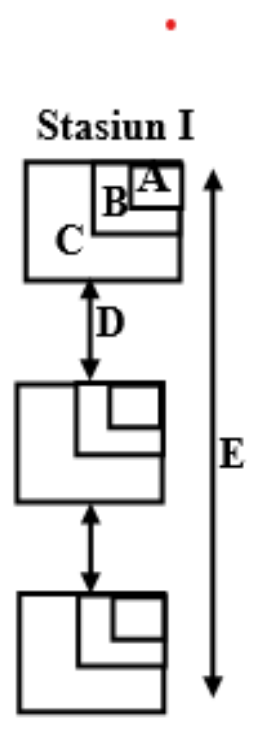

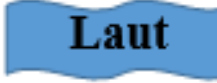

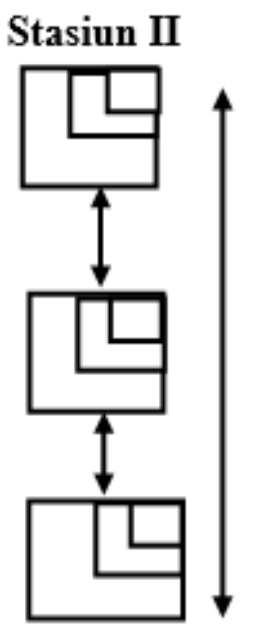

Daratan

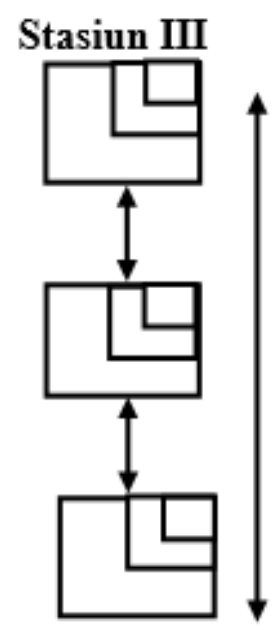

Gambar 2. Metode petak berganda 
Jurnal Laut Khatulistiwa, Vol. 4. No. 1 (Febuari, 2021), Hal. 56-63.

Tabel 1. Total jenis mangrove setiap stasiun di Desa Sungai Kupah

\begin{tabular}{lllccc}
\hline No & \multicolumn{1}{c}{ Spesies } & Famili & St 1 & St 2 & St 3 \\
\hline 1 & Avicenia lanata & Acanthaceae & 14 & 14 & 5 \\
2 & Avicenia marina & Acanthaceae & 9 & 14 & 5 \\
3 & Nypa fruticans & Arecaceae & 10 & $` 10$ & 15 \\
4 & Rhizophora apiculata & Rhizophoraceae & 1 & 1 & - \\
5 & Soneratia alba & Sonneratiaceae & - & 1 & - \\
\hline
\end{tabular}

Frekuensi digunakan untuk menyatakan proporsi antara jumlah sampel yang berisi suatu spesies tertentu terhadap jumlah total sampel. Frekuensi spesies tumbuhan adalah jumlah petak contoh tempat diketemukannya suatu spesies dari sejumlah petak contoh yang dibuat. Frekuensi jenis yang menunjukan jenis A. marina dan A. lanata memiliki nilai tertinggi pada tingkat pohon rata-rata 0,67 , tingkat pancang rata-rata sebesar 0,67 dan tingkat semai rata-rata sebesar 0,67 dan frekuensi relatif tingkat pohon rata-rata sebesar $63,33 \%$, tingkat pancang rata-rata sebesar $36,19 \%$ dan tingkat semai rata-rata $50 \%$. Hasil penelitian menunjukan nilai frekuensi relatif $A$. marina sebesar $63,33 \%$ A. marina dan $A$. lanata memiliki frekuensi relatif paling tinggi tingkat pancang disebabkan jenis ini dapat bertahan hidup karena didukung oleh faktor lingkungan sepertti substrat, salinitas dan suhu air dibandingkan jenis mangrove lainnya. sedangkan frekuensi relatif terendah adalah mangrove jenis $R$. apiculata hal ini yang menyebabkan jenis mangrove ini lebih sedikit dikarenakan persebaran yang tidak merata serta kurangnya adaptasi terhadap lingkungan disekitar (Tabel 3).

Indeks Nilai Penting (INP) adalah parameter kuantitatif yang dapat dipakai untuk menyatakan tingkat dominansi spesiesspesies dalam suatu komunitas tumbuhan. Spesies-spesies yang dominan dalam suatu komunitas tumbuhan akan memiliki indeks nilai penting yang tinggi, sehingga spesies yang paling dominan tentu saja memiliki indeks nilai penting yang paling besar, maka jenis itu sangat mempengaruhi kestabilan ekosistem mangrove tersebut. Jenis mangrove A. marina memiliki nilai INP tertinggi pada Stasiun 1 yang memiliki nilai INP sebesar $300 \%$. Sedangkan INP terendah tingkat pohon adalah mangrove jenis A. marina sebesar 111,74\% terdapat pada Stasiun 3 dikarenakan di daerah ini di dominasi jenis N.frutican. INP tertinggi tingkat pancang adalah mangrove jenis $N$. fruticans dengan nilai INP sebesar $95 \%$ yang terdapat pada Stasiun 3. Hal ini dikarenakan adaptasi terhadap lingkungan di lokasi penelitian sangat baik untuk pertumbuhan mangrove jenis $N$. fruticans. nilai INP terendah adalah mangrove jenis $R$. apiculata dan $S$. alba dengan nilai INP sebesar $19.55 \%$ yang tedapat pada Stasiun 2 rendahnya INP R. apiculata dan S.alba ini dikarenakan pada lokasi penelitian kondisi substratnya campuran tanah endapan dan lempung (Tabel 4)

Indeks keanekaragaman jenis untuk digunakan menentukan tegakan dalam suatu daerah yang menjadi ukuran dalam menilai proses suksesi yang berjalan dalam komunitas hutan tersebut. Tingkat keanekaragaman suatu hutan tinggi maka kondisi hutan tersebut seimbang (Irpan et al., 2017). Indeks keanekaragaman jenis mangrove di lokasi penelitian memiliki kisaran antara 0 - 1.11. Keanekaragaman jenis hutan yang tinggi untuk semua tingkat adalah di Stasiun 2 pada tingkat pancang yang dekat dengan pemukiman warga dengan nilai sebesar 1.11 sedangkan terendah terdapat pada tingkat pohon di stasiun 1 dengan nilai sebesar 0,35 . Hal ini menunjukan bahwa keanekaragaman jenis untuk semua tingkat pada hutan mangrove di Desa Sungai Kupah Kecamatan Sungai Kakap termasuk kategori rendah. Hal ini dikarenakan adanya aktivitas konversi lahan yang menjadikan lahan mangrove sebagai lahan pertanian, tempat wisata serta dekat jalur transportasi sehingga kondisi ini rentan terhadap kondisi jenis mangrove dikarenakan hasil dari mesin kapal nelayan sering tumpah dan menyebar disekitar akan mengendap di bagian akar 
Jurnal Laut Khatulistiwa, Vol. 4. No. 1 (Febuari, 2021), Hal. 56-63.

Tabel 2. Nilai kerapatan jenis dan Kerapatan Relatif

\begin{tabular}{|c|c|c|c|c|c|c|c|}
\hline \multirow[t]{2}{*}{ Stasiun } & $\begin{array}{l}\text { Jenis } \\
\text { Mangrove }\end{array}$ & Kerapa & an Jenis( $\mathrm{P}$ & hon/Ha) & Kerap & atan Relat & $f(\%)$ \\
\hline & & Pohon & Pancang & Semai & Pohon & Pancang & Semai \\
\hline \multirow[t]{5}{*}{ I } & Avicenia lanata & - & 666,67 & 13333,33 & - & 23,8 & 36,36 \\
\hline & Avicenia marina & 66,67 & 800 & 20000 & 100 & 28,57 & 54,54 \\
\hline & $\begin{array}{l}\text { Nypa frutican } \\
\text { Rhizopora }\end{array}$ & - & $1,333,33$ & - & - & 47,61 & - \\
\hline & apiculata & - & - & 3333,33 & - & - & 9,09 \\
\hline & Soneratia alba & - & - & - & - & - & - \\
\hline \multirow[t]{5}{*}{ II } & Avicenia lanata & 100 & 400 & 26666,67 & 60 & 15,78 & 50 \\
\hline & Avicenia marina & 66,67 & 533,33 & 26666,67 & 40 & 21,05 & 50 \\
\hline & $\begin{array}{l}\text { Nypa frutican } \\
\text { Rhizopora }\end{array}$ & - & 1333,33 & - & - & 52,63 & - \\
\hline & apiculata & - & 133,33 & - & - & 5,26 & - \\
\hline & Soneratia alba & - & 133,33 & - & - & 5,26 & - \\
\hline \multirow[t]{5}{*}{ III } & Avicenia lanata & 100 & 266,67 & - & 33,33 & 12,5 & - \\
\hline & Avicenia marina & 100 & 266,67 & - & 33,33 & 12,5 & - \\
\hline & $\begin{array}{l}\text { Nypa frutican } \\
\text { Rhizopora }\end{array}$ & 100 & 1600 & - & 33,34 & 75 & - \\
\hline & apiculata & - & - & - & - & - & - \\
\hline & Soneratia alba & - & - & - & - & - & - \\
\hline \multirow[t]{5}{*}{$\begin{array}{l}\text { Rata- } \\
\text { rata }\end{array}$} & Avicenia lanata & 100 & 444,45 & 20000,00 & 46,67 & 17,36 & 43,18 \\
\hline & Avicenia marina & 77,78 & 533,33 & 23333,33 & 36,67 & 20,71 & 52,27 \\
\hline & $\begin{array}{l}\text { Nypa frutican } \\
\text { Rhizopora }\end{array}$ & - & 1466,67 & - & 33,34 & 58,41 & - \\
\hline & apiculata & - & 133,33 & - & - & - & 9,09 \\
\hline & Soneratia alba & - & 133,33 & - & - & - & - \\
\hline
\end{tabular}

sehingga dapat mempengaruhi pertumbuhan jenis mangrove pada Stasiun 1 dan di Stasiun 2 dekat pemukiman penduduk (Tabel 5)

\subsection{Parameter lingkungan}

Salinitas di lokasi penelitian pada Stasiun 1, Stasiun 2 dan Stasiun 3 memiliki nilai salinitas 5\%o. Menurut Bengen (2002) menyatakan bahwa suatu ekosistem mangrove dapat hidup pada salinitas 2- $22 \%$ bahkan hingga perairan asin $38 \%$. Suhu perairan di lokasi penelitian berkisar antara $27.3-29.3^{\circ} \mathrm{C}$. Nilai rata- rata suhu perairan yang tertinggi terdapat di Stasiun 3 sebesar $29.3{ }^{\circ} \mathrm{C}$ sedangkan terendah terdapat pada Stasiun 1 yaitu sebesar $27.3^{\circ} \mathrm{C}$. Menurut Bengen (2002) menyatakan bahwa hutan mangrove mangrove tumbuh optimal pada suhu tropis yaitu di atas $20^{\circ} \mathrm{C}$.

Nilai $\mathrm{pH}$ pada lokasi penelitian berkisar antara 6,2 - 7,8. Nilai pH tertinggi terdapat pada Stasiun 2 dengan nilai sebesar 7,8 sedangkan terendah sebesar 6,2. Jenis substrat yang sesuai dengan pertumbuhan mangrove di Desa Sungai Kupah adalah campuaran tanah aluvial (endapan) dan lanau berpasir. Menurut Khairudin (2016) Sepanjang pesisir pantai juga dapat ditemukan pada di pantai barat pulau kalimantan yang berjenis tanah aluvial merupakan tanah endapan, dibentuk dari lumpur dan pasir halus yang mengalami erosi tanah. Banyak terdapat di dataran rendah, disekitar muara sungai, rawa-rawa, lembah-lembah, maupun di kanan kiri aliran sungai besar. 
Jurnal Laut Khatulistiwa, Vol. 4. No. 1 (Febuari, 2021), Hal. 56-63.

Tabel 3. Nilai Frekuensi Jenis dan Frekuensi Relatif

\begin{tabular}{|c|c|c|c|c|c|c|c|}
\hline \multirow[t]{2}{*}{ Stasiun } & \multirow[t]{2}{*}{ Jenis Mangrove } & \multicolumn{3}{|c|}{ Frekuensi Jenis (Pohon/Ha) } & \multicolumn{3}{|c|}{ Frekuensi Relatif (\%) } \\
\hline & & Pohon & Pancang & Semai & Pohon & Pancang & Semai \\
\hline \multirow[t]{5}{*}{ I } & Avicenia lanata & - & 0,67 & 0,33 & - & 40 & 25 \\
\hline & Avicenia marina & 0,67 & 0,67 & 0,67 & 100 & 40 & 50 \\
\hline & $\begin{array}{l}\text { Nypa frutican } \\
\text { Rhizopora }\end{array}$ & - & 0,33 & - & - & 20 & - \\
\hline & apiculata & - & - & 0,33 & - & - & 25 \\
\hline & Soneratia alba & - & - & - & - & - & - \\
\hline \multirow[t]{5}{*}{ II } & Avicenia lanata & 0,67 & 0,67 & 0,67 & 50 & 28,57 & 50 \\
\hline & Avicenia marina & 0,67 & 0,67 & 0,67 & 50 & 28,57 & 50 \\
\hline & $\begin{array}{l}\text { Nypa frutican } \\
\text { Rhizopora }\end{array}$ & - & 0,33 & - & - & 14,29 & - \\
\hline & apiculata & - & 0,33 & - & - & 14,29 & - \\
\hline & Soneratia alba & - & 0,33 & - & - & 14,29 & - \\
\hline \multirow[t]{5}{*}{ III } & Avicenia lanata & 0,67 & 0,67 & - & 40 & 40 & - \\
\hline & Avicenia marina & 0,67 & 0,67 & - & 40 & 40 & - \\
\hline & $\begin{array}{l}\text { Nypa frutican } \\
\text { Rhizopora }\end{array}$ & 0,33 & 0,33 & - & 20 & 20 & - \\
\hline & apiculata & - & - & - & - & - & - \\
\hline & Soneratia alba & - & - & - & - & - & - \\
\hline \multirow[t]{5}{*}{$\begin{array}{l}\text { Rata- } \\
\text { rata }\end{array}$} & Avicenia lanata & 0,67 & 0,67 & 0,5 & 45 & 36,19 & 37,5 \\
\hline & Avicenia marina & 0,67 & 0,67 & 0,67 & 63,33 & 36,19 & 50 \\
\hline & $\begin{array}{l}\text { Nypa frutican } \\
\text { Rhizopora }\end{array}$ & 0,33 & 0,33 & 0,33 & 20 & 18,10 & - \\
\hline & apiculata & - & 0,33 & - & - & - & 25 \\
\hline & Soneratia alba & - & 0,33 & - & - & - & - \\
\hline
\end{tabular}

\subsection{Zonasi Mangrove}

Hasil analisis data pola sebaran zonasi mangrove di Desa Sungai Kupah Kecamatan Sungai Kakap menunjukan adanya dominansi jenis mangrove tertentu karena adanya pengaruh beberapa faktor lingkungan dan faktor manusia. Hal ini terlihat pada sebaran spesies A. marina dan A. lanata yang mendominasi sebaran mangrove pada Stasiun 1, Stasiun 2 dan Stasiun 3 di dominasi jenis mangrove $N$. fruticans. Pada awal nya semua Stasiun ini merupakan hutan mangrove alami, hanya beberapa lahan telah berubah di karenakan adanya pembangunan tempat wisata dan dekat dengan jalur transportasi.

\section{Kesimpulan}

Terdapat 5 jenis mangrove di Desa Sungai Kupah Kecamatan Sungai Kakap yang terdiri atas Avicenia marina, Avicenia lanata, Rhizopora apiculata, Soneratia alba, Nypa frutican. Jenis mangrove yang mendominansi di lokasi adalah jenis Avicenia marina yang memiliki komposisi paling tinggi dari semua jenis mangrove yang ditemukan di Desa Sungai Kupah Kecamatan Sungai Kakap. Hal ini dikarenakan A. marina lebih banyak ditemukan dan memiliki kemampuan beradaptasi dengan baik terhadap lingkungannya yang selalu terendam sehingga menghasilkan substrat berlumpur. Pola penyebaran individu setiap jenis umumnya sesuai dengan zonasi mangrove di lokasi. Pada Stasiun 1 dan 2 zona terdepan atau menghadap kearah laut didominasi jenis mangrove $A$. 
Jurnal Laut Khatulistiwa, Vol. 4. No. 1 (Febuari, 2021), Hal. 56-63.

Tabel 4. Nilai indeks keanekaragaman

\begin{tabular}{cccc}
\hline \multirow{2}{*}{ Stasiun } & \multicolumn{3}{c}{ Indeks Keanekaragaman (H') } \\
\cline { 2 - 4 } & Pohon & Pancang & Semai \\
\hline I & 0,35 & 1,02 & 0,91 \\
II & 0,67 & 1,11 & - \\
III & 1,09 & 0,73 & - \\
\hline
\end{tabular}

Tabel 5. Nilai Parameter Lingkungan

\begin{tabular}{ccccl}
\hline Stasiun & Suhu & Salinitas & $\mathrm{pH}$ & \multicolumn{1}{c}{ Substrat } \\
\hline 1 & 27,3 & 5 & 6,2 & $\begin{array}{l}\text { Campuran tanah endapan dan } \\
\text { lempung } \\
\text { Campuran tanah endapan dan }\end{array}$ \\
2 & 26,7 & 5 & 7,8 & $\begin{array}{l}\text { lempung } \\
\text { Campuran tanah endapan dan } \\
3\end{array}$ \\
\hline
\end{tabular}

marina dan A. lanata, zona tengah ditumbuhi mangrove jenis $R$. apiculata dan S.alba dan zona belakang dekat dengan daratan ditumbuhi oleh jenis mangrove $N$. fruticans sedangkan pada Stasiun $3 \mathrm{~N}$. frutican pada bagian depan zona tengah A.marina dan A.lanata.

\section{Daftar Pustaka}

Bengen, D. G., 2002. Pedoman teknik pengenalan dan pengelolaan ekosistem mangrove. Pusat Kajian Sumberdaya Pesisisr dan Laut. Bogor : Institut pertanian Bogor.

Fachrul, M.F., 2007. Metode Sampling Bioteknologi . Bumi Aksara. Jakarta 198

Indriyanto., 2006. Ekologi Hutan. Bumi Aksara Jakarta

Irpan, F. B., T. F. Manurung dan Muflihati, 2017. Komposisi dan Struktu Vegetasi Penyusun Zonasi Hutan Mangrove Tanjung Prapat Muda Tanjung Bakau Kabupaten Kubu Raya. Jurnal Hutan Lestari. 5: $104-112$

Kementerian Lingkungan Hidup dan Kehutanan, 2018. Hasil pengolahan Data peta mangrove pulau Kalimantan

Khairudin, B. 2016. Strategi Kebijakan Pengelolaan Ekosistem Mangrove Secara Terpadu dan Berkelanjutan di Kabupaten Pontianak Provinsi Kalimantan Barat. Bogor : Institut Pertanian Bogor
Tarigan, M. S. 2008. Sebaran dan Luasan Hutan Mangrove di Wilayah Teluk Pising Utara Pulau Kabaena Provinsi Sulawesi Tenggara. Makara Sains. 12(2): 108 112 